NBER WORKING PAPER SERIES

\title{
INNOVATION AND PRODUCTIVITY IN SMES: EMPIRICAL EVIDENCE FOR ITALY
}

\author{
Bronwyn H. Hall \\ Francesca Lotti \\ Jacques Mairesse \\ Working Paper 14594 \\ http://www.nber.org/papers/w14594
}

\author{
NATIONAL BUREAU OF ECONOMIC RESEARCH \\ 1050 Massachusetts Avenue \\ Cambridge, MA 02138 \\ December 2008
}

We would like to thank the Mediocredito-Capitalia research department for having kindly supplied firm level data for this project. We thank also Susanto Basu, Ernie Berndt, Piergiuseppe Morone, Mike Scherer, Alessandro Sembenelli, Marco Vivarelli, and participants at the NBER Productivity Seminars and at the workshop "Drivers and Impacts of Corporate R\&D in SMEs" held in Seville at ITPS. The views expressed herein are those of the authors and do not necessarily reflect the views of the Bank of Italy or the National Bureau of Economic Research.

NBER working papers are circulated for discussion and comment purposes. They have not been peerreviewed or been subject to the review by the NBER Board of Directors that accompanies official NBER publications.

(C) 2008 by Bronwyn H. Hall, Francesca Lotti, and Jacques Mairesse. All rights reserved. Short sections of text, not to exceed two paragraphs, may be quoted without explicit permission provided that full credit, including ( $)$ notice, is given to the source. 
Innovation and Productivity in SMEs: Empirical Evidence for Italy

Bronwyn H. Hall, Francesca Lotti, and Jacques Mairesse

NBER Working Paper No. 14594

December 2008

JEL No. D24,L25,L26,O30,O32

\begin{abstract}
$\underline{\text { ABSTRACT }}$
Innovation in SMEs exhibits some peculiar features that most traditional indicators of innovation activity do not capture. Therefore, in this paper, we develop a structural model of innovation which incorporates information on innovation success from firm surveys along with the usual R\&D expenditures and productivity measures. We then apply the model to data on Italian SMEs from the "Survey on Manufacturing Firms" conducted by Mediocredito-Capitalia covering the period 1995-2003. The model is estimated in steps, following the logic of firms' decisions and outcomes: in the first, R\&D intensity is linked to a set of firm and market characteristics. We find that international competition fosters R\&D intensity, especially for high-tech firms. Firm size, R\&D intensity, along with investment in equipment enhances the likelihood of having both process and product innovation. Both these kinds of innovation have a positive impact on firm's productivity, especially process innovation. Among SMEs, larger and older firms seem to be less productive.
\end{abstract}

Bronwyn H. Hall

Dept. of Economics

549 Evans Hall

UC Berkeley

Berkeley, CA 94720-3880

and NBER

bhhall@nber.org

Francesca Lotti

Structural Economic Analysis Department

Bank of Italy

via Nazionale 91, 00184 Rome (IT)

francesca.lotti@gmail.com
Jacques Mairesse

INSEE, CREST

15, Boulevard Gabriel PERI

92245 MALAKOFF CEDEX

FRANCE

and NBER

mairesse@ensae.fr 


\section{Introduction}

In the past decade, labor productivity growth in Italy has been one of the lowest in the $\mathrm{EU}$; low growth has been particularly strong in manufacturing, where the growth rate even turned negative in the period from 2000 to 2005 (see Figure 1). Such a poor performance raises unavoidable policy concerns about the underlying reasons for it. Is the labor productivity slowdown due to the decline in total factor productivity (see Daveri and Jona-Lasinio 2005)? Or, more precisely, is it a consequence of the exhaustion of the so-called "capital deepening" phase that supported labor productivity growth during the Eighties (as documented by Pianta and Vaona, 2007)? Alternatively, is it simply due to input reallocation following a change in the relative price of labor with respect to capital after the labor market reforms of the early 1990s (Brandolini et al., 2007)? Or does the explanation lie in the evergreen motto that Italian firms exhibit insufficient R\&D investment (European Commission, 2006)?

The latter aspect has been largely explained by the unquestionable fragmentation of the Italian production system. According to the latest available data from the Census, more than 99 per cent of active firms (out of 4 million) have fewer than 250 employees (95 per cent have fewer than 10 employees, see Figure 2). If there were a positive relationship between innovation activity - including R\&D - and firm size, the size distribution on Italian firms could help to explain why Italy is lagging behind in terms of aggregate $\mathrm{R} \& \mathrm{D}$ investment.

Nevertheless, many scholars have argued that small firms are the engines of technological change and innovative activity, at least in certain industries (see the series of works by Acs and Audretsch, 1988, 1990). But at the same time, innovation in small and medium enterprises exhibits some peculiar features that most traditional indicators of innovation activity would not capture, incurring the risk of underestimating their innovation effort. In fact, innovation often occurs without the performance of formal $\mathrm{R} \& \mathrm{D}$, and this is particularly true for SMEs. Despite the existence of a large number of policies designed to promote and facilitate the operation of the innovation process within SMEs, especially in Italy, the knowledge about how SMEs actually undertake innovative activities remains quite limited, causing a significant bias in the treatment of 
the R\&D - innovation relationship (see Hoffman et al, 1998 for a literature review on this topic in the UK).

This paper is not an attempt to verify or disprove the Schumpeterian hypothesis, i.e. to study the relationships between firm size and innovative activity at the firm level; instead it investigates how and when innovation takes place in SMEs and whether and how - innovation outcomes impact SME firms' productivity. We caution the reader that because we rely mainly on dummy variables for the present of innovation success, we are in fact unable to say very much about the size-innovation relationship per se. In general larger firms have more of any activity, and this will include innovative activity, which implies a higher probability that the innovation dummy is one.

The remainder of the paper is organized as follows. Section 2 contains a summary - far from being exhaustive - of the previous empirical studies on the innovationproductivity link, with a few cross country comparisons. In Section 3, the econometric model is explained, along with a description of the data used in this analysis; Section 4 concludes with a discussion of the results and with directions for further research.

\section{Previous studies of the innovation - productivity link}

Measuring the effects of innovative activities on firms' productivity has been an active area for research for several decades both as a policy concern and as a challenge for econometric applications. Notwithstanding a large number of empirical studies available, measuring the effect of innovation (product and process) on productivity at the firm level (see Griliches, 1995), the literature still does not provide a unique answer in terms of the magnitude of this impact. Because of the variability and uncertainty that is inherent in innovation, this fact is not unexpected: at best, economic research should give us a distribution of innovation outcomes and tell us how they have changed over time. Recent firm level studies, Lichtenberg and Siegel (1991) on the U.S., Hall and Mairesse (1995) on France, Harhoff (1998) and Bönte (2003) on Germany, Klette and Johansen (1996) on Norway, Janz et al (2004) on Germany and Sweden, Lööf and Heshmati (2002) on Sweden, Lotti and Santarelli (2001) and Parisi et al (2006) on 
Italy, find that the effect of $R \& D$ on productivity is positive, ${ }^{1}$ although some have suggested that the returns to R\&D have declined over time (Klette and Kortum, 2004). The majority of the empirical analyses rely on an extended production-function approach, which includes $R \& D$ (or alternative measures of innovation effort) as another input to production.

However, it is widely recognized that R\&D does not capture all aspects of innovation, which often occurs through other channels. This is particularly true for small and medium-size firms, and could lead to a severe underestimation of the impact of innovation on productivity. In order to overcome this problem, subsequent studies have moved from an input definition of innovation activities to an output approach, by including in the regressions the outcome of the innovation process rather than its input. The rationale behind this line of reasoning is simple: if it is not possible to measure the innovative effort a firm exerts because of the presence of latent and unobservable variables, one should look at the results of R\&D investment: training, technology adoption, sales of products new to the market or the firm. All these activities may be signs of successful innovative effort, but if one considers R\&D only, a lot of this informal activity is going to be missing from the analysis (Blundell et al., 1993, Crépon, Duguet and Mairesse, 1998). As suggested by Kleinknecht (1987), official R\&D measures for SMEs may underestimate their innovation activities, and the underestimate is likely to be larger at the left end of the firm size distribution.

Crépon, Duguet and Mairesse (1998) take a further step in this literature combining the aforementioned approaches. They propose and estimate a model - CDM model hereinafter - that establishes a relationship among innovation input (mostly, but not limited, to R\&D), innovation output and productivity. The structural model allows a closer look at the black box of the innovation process at the firm level: it not only analyzes the relationship between innovation input and productivity, but it also sheds some light on the process in between the two.

The CDM approach is based on a three-step model following the logic of firms' decisions and outcomes in terms of innovation. In the first step, firms decide whether to

\footnotetext{
${ }^{1}$ For a survey of previous empirical results, see Griliches (1998).
} 
engage in $R \& D$ or not and the amount of resources to invest. Given the firm's decision to invest in innovation, the second step is characterized by a knowledge production function (as in Pakes and Griliches, 1984) in which innovation output stems from innovation input and other input factors. In the third step, an innovation augmented Cobb-Douglas production function describes the effect of innovative output on the firm's productivity. The model is specifically designed to work well with innovation survey data, from which it is possible to directly measure other aspects of innovation in addition to R\&D expenditures. Given the increased diffusion of this type of micro data across countries and among scholars, many empirical explorations of the impact of innovation on productivity have relied on the CDM framework. ${ }^{2}$

In particular, Parisi, Schiantarelli and Sembenelli (2006) apply a modified version of the CDM model to a sample of Italian firms (using two consecutive waves of the Mediocredito-Capitalia survey, the same source we are using in our empirical analysis), enriching the specification with a time dimension. ${ }^{3}$ They find that process innovation has a large and significant impact on productivity and that R\&D is positively associated with the probability of introducing a new product, while the likelihood of having process innovation is directly linked to firm's investment in fixed capital. In comparing those results from the ones we obtain in this paper, one has to keep in mind that, due to the design of the survey itself, the panel used by Parisi, Schiantarelli and Sembenelli is tilted towards medium and large firms much more than the original MediocreditoCapitalia sample.

To our knowledge, none of the empirical papers dealing with the link between innovation and productivity has dealt specifically with small and medium-sized firms. On one hand, this paper is aimed at filling this gap, since innovation in SMEs is even more difficult to measure; on the other, like Griffith et al (2007) we try to improve the

\footnotetext{
${ }^{2}$ See Hall and Mairesse (2006) for a comprehensive survey. Recent papers based on the CDM model include Benavente (2006) on Chile, Heshmati and Lööf, (2006) on Sweden, Jefferson et al. on China, Van Leeuwen and Klomp (2001) on the Netherlands, Mohnen, Mairesse and Dagenais (2006) on seven European countries, and Griffith, Huergo, Mairesse and Peters (2006) on four European countries.

3 Although the Mediocredito-Capitalia survey is not a panel itself, it contains repeated observation for a number of firms enough to allow a dynamic framework. See Section 3 of this paper for further information on the data.
} 
CDM model specification allowing our model to separate the impact of different kinds of innovation (product and process) on firms' productivity.

\section{Data and Methodology}

The data we use come from the $7^{\text {th }}, 8^{\text {th }}$ and $9^{\text {th }}$ waves of the "Survey on Manufacturing Firms" conducted by Mediocredito-Capitalia (an Italian commercial bank). These three surveys were carried out in 1998, 2001, and 2004 respectively, using questionnaires administered to a representative sample of Italian manufacturing firms. Each survey covered the three years immediately prior (1995-1997, 1998-2000, 2001-2003) and although the survey questionnaires were not identical in all three of the surveys, they were very similar in the sections used in this work. All firms with more than 500 employees were included, whereas smaller firms were selected using a sampling design stratified by geographical area, industry, and firm size. We merged the data from these three surveys, excluding firms with incomplete information or with extreme observations for the variables of interest. ${ }^{4}$ We focus on SMEs, which represent nearly 90 per cent of the whole sample, imposing a threshold of 250 employees, in line with the definition of the European Commission; we end up with an unbalanced panel of 9,674 observations on 7,375 firms, of which only 361 are present in all three waves. Table 1 contains some descriptive statistics, for both the unbalanced and the balanced panel. Not surprisingly, in both cases, the firm size distribution is skewed to the right for both groups of firms, with an average of around 50 and 53 employees respectively. Firms in the low-tech sector tend to be slightly smaller, with average employment of 47 and median employment of 30 (Table 2). ${ }^{5}$ In the unbalanced sample, $62 \%$ of the firms

\footnotetext{
${ }^{4}$ We require that sales per employee be between 2000 and 10 million euros, growth rates of employment and sales of old and new products between -150 per cent and 150 per cent, and R\&D employment share less than 100 per cent. We also replaced R\&D employment share with the R\&D to sales ratio for the few observations where it was missing. For further details, see Hall, Lotti and Mairesse (2008). In addition, we restrict the sample by excluding a few observations with zero or missing investment.

${ }^{5}$ We adopt the OECD definition for high- and low-tech industries. High-tech industries: encompasses high and medium-high technology industries (chemicals; office accounting \& computer machinery; radio, TV \& telecommunication instruments; medical, precision \& optical instruments; electrical machinery and apparatus, n.e.c.; machinery \& equipment; railroad \& transport equipment, n.e.c.). Low-tech industries: encompasses low and medium-low technology industries (rubber \& plastic
} 
engage in innovation activity on average, but only $41 \%$ invest in R\&D. This difference is an indirect signal of the presence of alternative - presumably informal - sources of innovation. Although a sizeable share of firms invests on $R \& D$, only a small fraction seems to do it continuously: out of 361 firms in our balanced panel, $34 \%$ invest in R\&D in every period under examination. For $21 \%$ of the firms product and process innovations go together, while $27 \%$ are process innovators only. Concerning competition, more than $42 \%$ of the firms in the sample have national competitors, while $18 \%$ and $14 \%$ have European and international competitors, respectively. Interestingly, low-tech firms tend to compete more within the national boundaries, while almost half of the high-tech firms operate in European or international markets, in line with Janz et al. (2004).

For comparison, in Table A1 of the appendix we show the means for our entire sample, including non-SMEs and excluding firms with fewer than 20 employees, for comparability the samples used by Griffith et al (2006) for France, Germany, Spain and UK. Even if the share of innovators - product and process - are not dissimilar, Italian firms display a significantly lower R\&D intensity but roughly comparable investment intensities. These figures can be partially explained by the different firm size distribution within each country: around 60 per cent of the firms in the Italian sample for the year 2000 belong to the smaller class size (20-49 employees), a figure much larger than that for other countries. ${ }^{6}$ Interestingly, labor productivity is somewhat higher for the Italian firms.

As discussed earlier, in order to analyze the relationship between $R \& D$, innovation and productivity at the firm level, we rely on a modified version of the model proposed by Crépon, Duguet and Mairesse (1998, CDM hereinafter). Their model - specifically tailored for innovation survey data and built to take into account the econometric issues that arise in this context - is made up by three blocks, following the logic of firms'

products; coke, refined petroleum products; other non-metallic mineral products; basic metals and fabricated metal products; manufacturing n.e.c.; wood, pulp \& paper; food, beverages \& tobacco products; textile, textile products, leather \& footwear).

\footnotetext{
${ }^{6}$ We do not yet know how much of the difference is due to differences in sampling strategy across the different countries.
} 
decisions and outcomes in terms of innovation. The first step models the R\&D decision, i.e. the process that leads the firm to decide whether to undertake $R \& D$ projects or not and, given its willingness to invest, how much to spend on R\&D. The second step is a knowledge production function in which $R \& D$ is one of the inputs, among other firms' characteristics; as output, firms can produce process and/or product innovation. The third and last step is a simple production function in which knowledge is one of the inputs.

In every step we repeat the analysis for the whole sample of firms, for high- and lowtech firms, since the effect of $\mathrm{R} \& \mathrm{D}$ on productivity can vary a lot with the technological content of an industry (see Verspagen, 1995 for a cross country, cross sector study and, more recently, an analysis based on micro data by Potters et al, 2008).

Because of the way our data and innovation survey data in general is collected, the analysis here is essentially cross-sectional. Although there are three surveys covering 9 years, the sampling methodology used means that few firms appear in more than one survey (as we saw in Table 1, fewer than 5 per cent of the firms and about 10 per cent of the observations are in the balanced panel). Therefore, the use of fixed firm effect models was not feasible due to the resulting small sample size and limited information in the time series dimension. In addition, the innovation data are collected retrospectively (innovating over the past three years), and the income statement data is mostly contemporaneous. As a robustness check we estimated the same 3 equation model using R\&D intensity lagged one year instead of contemporaneous R\&D intensity in order to account for the possible timing delay in the output of R\&D. Given the low volatility of $R \& D$ investment over time, the results were very similar to those reported below. ${ }^{7}$

\footnotetext{
${ }^{7}$ Although we did not include these results in the paper for the sake of brevity, they are available from the authors.
} 


\subsection{The $R \& D$ decision}

At this stage, a firm must decide whether to engage in $R \& D$ or not, then, given that the firm chooses to invest, it must choose R\&D intensity. This statement can be simply modeled with a selection model where

$$
R D I_{i}=\left\{\begin{array}{lll}
1 & \text { if } & R D I_{i}^{*}=w_{i} \alpha+\varepsilon_{i}>\bar{c} \\
0 & \text { if } & R D I_{i}^{*}=w_{i} \alpha+\varepsilon_{i} \leq \bar{c}
\end{array}\right.
$$

defines the R\&D decision. $R D I_{i}$ is an (observable) indicator function that takes value 1 if firm $i$ has (or reports) positive $\mathrm{R} \& \mathrm{D}$ expenditures, $R D I_{i}{ }^{*}$ is a latent indicator variable such that firm $i$ decides to perform (or to report) R\&D expenditures if they are above a given threshold $\bar{c}, w_{i}$ is a set of explanatory variables affecting $\mathrm{R} \& \mathrm{D}$ and $\varepsilon_{i}$ the error term. For those firms doing $R \& D$, we can observe the amount of resources devoted to it.

Accordingly,

$$
R D_{i}=\left\{\begin{array}{lll}
R D_{i}^{*}=z_{i} \beta+e_{i} & \text { if } & R D I_{i}=1 \\
0 & \text { if } & R D I_{i}=0
\end{array}\right.
$$

where $R D_{i}^{*}$ is the unobserved latent variable accounting for firm's innovative effort, $z_{i}$ is a set of determinants of $R \& D$ expenditures. Assuming that the error terms in (1) and (2) are bivariate normal with zero mean and variance equal to unity, the system of equation (1) and (2) can be estimated by maximum likelihood. In the literature, this model is sometimes referred to as a Heckman selection model (Heckman, 1979) or Tobit type II model (Amemiya, 1984).

Before estimating the selection model, we performed a non parametric test for the presence of selection bias in the R\&D intensity equation (see Das, Newey and Vella, 2003, and Vella, 1998 for a survey). In so doing, we first estimate a probit model in which the presence of positive $R \& D$ expenditures is regressed on a set of firm characteristics: firm size, age and their squares, a set of dummies indicating competitors' size and location, dummy variables indicating (i) whether the firm received government subsidies, and (ii) whether the firm belongs to an industrial group; the results are reported in Table A2 in the appendix. From this estimate, for each firm we recover the predicted probability of having $R \& D$ and the corresponding Mills' ratio. Then we estimate a simple linear (OLS) for R\&D intensity, adding to this equation the 
predicted probabilities from the $\mathrm{R} \& \mathrm{D}$ decision equation, the Mills' ratio, their squares and interaction terms. The presence of selectivity bias is then tested for by looking at the significance of those "probability terms". ${ }^{8}$ The results are reported in Table A2 in the appendix. As one can see, the probability terms are never significant, either singly or jointly. Therefore we adopted a simple OLS model for the R\&D intensity decision since it appears that there is no selectivity bias. The results are reported in Table 3: estimates are performed using the pooled sample, including in the regression time, 2digit industry and "wave dummies" as controls. Wave dummies are a set of indicators for firm's presence or absence in the three waves of the survey. ${ }^{9}$

Table 3 shows that the presence of EU and international competitors is strongly positively related to $R \& D$ effort: engaging in exporting activity implies being more specialized in the products and investing more in R\&D (see Baldwin, Beckstead, and Caves, 2002, and Baldwin and Gu, 2004, for an exploration using Canadian data), and this effect is particularly strong for high-tech firms, where competing internationally is associated with a doubling of $R \& D$ intensity. Non-exporting firms, i.e. those operating in a market that is mainly local, have, on average, lower R\&D intensity.

We also find that having received a subsidy boosts innovation efforts ${ }^{10}$ or, at least, the likelihood of reporting positive $R \& D$ expenditures. Being part of an industrial group increases R\&D intensity, but the coefficient is barely statistically significant.

We also included age classes dummies in the regression (the base group are younger firms, defined as those with less than 15 years): although the coefficients are not statistically significant, they seem to indicate that older firms may have a slightly lower incentive to do R\&D than younger firms. Also, (relatively) larger firms tend to do less R\&D per employee than small firms (the 11-20 size class), and this is particularly true

\footnotetext{
${ }^{8}$ Note that this is a generalization of Heckman's two step procedure for estimation when the error terms in the two equations are jointly normally distributed. The test here is valid even if the distribution is not normal.

${ }^{9}$ For instance, a firm present in all the three waves will have a " 111 " code, "100" if present in the first only, " 110 " if in the first and in the second only, and so forth. These codes are transformed into a set of six dummies $\left(2^{3}=8\right.$ minus the 000 case and the exclusion restriction). subsidies.

${ }^{10}$ Due to the large number of missing observation, we could not use a narrower definition of
} 
for low-tech firms (for a discussion of the relationship between size and R\&D investment at the firm level, see Cohen and Klepper, 1996).

\subsection{The knowledge production function}

In the second step, we estimate a knowledge production function but, like Griffith et al. (2006), in order to account for that part of innovation activity that has not been formalized, we do not restrict estimation to $R \& D$ performing firms only. This is likely to be especially important for SMEs. The outcomes of the knowledge production function are product and process innovation,

$$
\left\{\begin{array}{l}
\operatorname{PROD}_{i}=R D_{i}^{*} \gamma+x_{i} \delta+u_{1 i} \\
\operatorname{PROC}_{i}=R D_{i}^{*} \gamma+x_{i} \delta+u_{2 i}
\end{array}\right.
$$

where $R D_{i}^{*}$ is the latent innovation effort proxied by the predicted value of $\mathrm{R} \& \mathrm{D}$ intensity from the first step model, $x_{i}$ a set of covariates and $u_{1 i}$ and $u_{2 i}$ the error terms such that $\operatorname{Cov}\left(u_{1 i}, u_{2 i}\right)=\rho$. We argue that including the predicted R\&D intensity in the regression accounts for the fact that all firms may have some kind of innovative effort, but only some of them report it (Griffith et al, 2006). Moreover, using the predicted value instead of the realized value is a sensible way to instrument the innovative effort in the knowledge production function in order to deal with simultaneity problem between $R \& D$ effort and the expectation of innovative success.

Equation (3) is estimated as a bivariate probit model, assuming that most of the firm characteristics which affect product and process innovation are the same, although of course their impact may differ. The only exception is the investment rate, which is assumed to be related to process innovation but not to product innovation. Table 4 reports the results from the whole sample of firms, and then for the sample split into high and low tech firms. The estimated correlation coefficient $\rho$ is always positive and significant, which implies that process and product innovation are influenced to some extent by the same unobservable factor. Marginal effects are reported in square brackets. For an example of how to interpret these effects, the first two columns say that a doubling of predicted $R \& D$ intensity is associated with a 0.19 increase in the probability of process innovation and a 0.25 increase in the probability of product innovation. 
As expected, the R\&D intensity predicted by the first equation has a positive and sizeable impact on the likelihood of having product and process innovation, higher for product innovation, for all three groups of firms. Interestingly, the impact of $R \& D$ on process innovation in low tech firms is more than double that for high-tech firms $(0.24$ versus 0.10 ). Firms in low tech industries, on average, have lower R\&D intensity, but their R\&D effort leads to a higher probability of having at least one process innovation when compared to high-tech firms. A number of interpretations suggest themselves: one possibility is that innovating in this sector takes less $R \& D$ because it involves changes to the organization of production that are not especially technology-linked. A second related interpretation is provided by the dual role of $R \& D$ (Cohen and Levinthal, 1989): investment in research is fundamental for product innovation, but at the same time, it increases firm's ability to absorb and adopt those technologies developed somewhere else which are likely to become process innovation.

As suggested in the introduction, firm size is strongly associated with innovative success, especially among low-tech firms. Although this result is in contrast with that for R\&D intensity, because innovation is measured by a dummy variable, there is no inconsistency. Although larger firms may have somewhat lower R\&D effort given their size, in absolute terms they do more $\mathrm{R} \& \mathrm{D}$, so there is a higher probability of innovative success. Finally, with the exception of product innovation in firms older than 25 years, the age of the firm is not particularly associated with innovation of either kind.

We also note that investment intensity is positively associated with process innovation in both high and low tech firms. We defer a fuller discussion of the issues associated with the presence of investment in these equations until after we present the productivity results.

\subsection{The productivity equation}

In the third and final step of the model, production takes place using a simple CobbDouglas technology with constant returns to scale, and with labor, capital, and knowledge inputs:

$$
y_{i}=\pi_{1} k_{i}+\pi_{2} P R O D_{i}+\pi_{3} P_{R O C_{i}}+v_{i}
$$


where $y_{i}$ is labor productivity (sales per employee, in logs), $k_{i}$ is investment intensity, our proxy for physical capital, $P R O D_{i}$ and $P R O C_{i}$ are knowledge inputs, proxied by product and process innovation indicators respectively. In order to address the possible endogeneity issue concerning the knowledge inputs, we use their predicted probabilities coming from the knowledge production function (the second step). More precisely, we generate two predicted probabilities of innovation from those equations: one of process innovation alone and one for product innovation, whether or not it is accompanied by process innovation. ${ }^{11}$ Results are reported in Table 5 for specifications with and without investment as a proxy for capital; as before, estimates are reported separately for all firms, high- and low-tech industries. Our preferred specifications (1a, 2a, 3a) include investment intensity.

When investment is not included in the regression, process innovation displays a sizeable and positive impact on productivity for all the categories of firms under exam, column (1), (2) and (3). Process innovators have a productivity level approximately two and one half times that of non-innovators, ceteris paribus. On the contrary, when investment is included, the coefficients of process innovation are not significant, because the same investment variable was included in the previous step in order to predict process innovation. Thus the coefficient of process innovation in the productivity equation already encompasses the effect of investment in new machinery and equipment. However, because the investment rate is a better measure than the process innovation dummy, when both are included, it tends to dominate.

Product innovation enhances productivity considerably, although to a lesser extent than process innovation. The impact is slightly stronger for high-tech firms. Because much of product innovation is directed towards higher quality products and product differentiation, it is perhaps not surprising that it does not show up as immediately as process innovation in the productivity relation. Table A3 in the appendix also shows that the contribution of product innovation to productivity is much more robust to the inclusion of investment intensity, whether or not investment intensity is used included in the second step.

\footnotetext{
${ }^{11}$ The first is estimated probability of process and not product from the bivariate probit model in Table 4, and the second is the marginal probability of product innovation from the same model.
} 
Interestingly, among SMEs. relatively larger firms seem to be less productive than smaller ones. For high-tech firms only, age impacts productivity negatively.

\subsection{Investment and innovation}

In our preferred specification in Table 4 , we assumed that capital investment - which to a great extent means the purchase of new equipment - should contribute significantly to process innovation, but not to product innovation. In fact, we found a small marginal impact of investment on process innovation that was approximately the same for high and low-tech industries (0.05).

Because the assumption that investment is associated with process and not with product innovation may be somewhat arbitrary, we performed some robustness checks reported in Table A3 in the appendix, experimenting with different alternatives. Columns (1)-(4) of that Table reports all the possible combinations in the second step: whether investment is devoted to process innovation only (column 1), to product innovation

only (column 2), to both (column 3) or to none (column 4). In the same columns we show the third step, the productivity equation, estimated using each of these different models to predict the probability of process and product innovation. In the bottom panel of the table, we report an alternative specification of the productivity equation without investment. Although column (1) still represents our preferred specification, column (3) suggests that physical investment has a small (0.02) positive impact on product innovation as well. Turning to the productivity equation, it can be noted that the inclusion of investment wipes out the significance of process innovation, since investment is one of its main determinants, but not of product innovation, which is more dependent on R\&D investment. Excluding investment from the productivity equation reveals that the process innovation associated with investment is more relevant for productivity than predicted product innovation (compare the process innovation coefficients for step 3 in columns 1 and 3).

\subsection{Further robustness checks}

The estimation method used in the body of the paper is sequential, with three steps: 1) the $R \& D$ intensity equation estimated only on firms that report doing $R \& D$ continuously; 2) A bivariate probit for process and product innovation that contains 
R\&D predicted by the first step for all firms; and 3) a productivity equation that contains the predicted probabilities for process innovation alone and product innovation with or without process innovation. Because the last two steps contain fitted or predicted values, their standard errors will be underestimated by our sequential estimation method. In order to assess the magnitude of this underestimation, we reestimated our preferred model (1a) on all firms simultaneously using maximum likelihood.

The likelihood function consists of the sum of a normal density for the R\&D equation, a bivariate probit for process and product innovation, and a normal density for the productivity equation; it does not allow for correlation of the disturbances between the three blocks, although the resulting standard errors are robust to such correlation. In this likelihood function, the equation for $R \& D$ is directly entered into the innovation equations, and that for innovation probability directly into the productivity equation, so the coefficient standard errors take account of the estimation uncertainty in the first two stages.

The results of estimation on the pooled model are shown in column (2) of Tables A4 in the appendix, with the sequential estimation results in column (1) for comparison. ${ }^{12}$ Although the results for the key coefficients are similar and have approximately the same significance, the standard errors from pooled maximum likelihood are considerably larger, especially for the predicted process and product probabilities. So this should be kept in mind when interpreting the results in the tables of the paper.

Table A4 also shows the results of another experiment -- in this paper we chose to proxy capital intensity by investment intensity, in order to be comparable to the results in Griffith et al. 2006. However, in our data we also have a measure of capital available, constructed from investment using the usual declining balance method with a depreciation rate of 5 per cent and an initial stock from the balance sheet of the firm in 1995 or the year it entered the survey. Columns (3)-(5) of the table show the results of estimating specifications containing capital stock at the beginning of the period and using the pooled maximum likelihood method. Column (3) simply replaces investment

\footnotetext{
12 The sample size in this table is 9,014, reduced from 9,674 in the main tables of the paper due to the absence of lagged capital (beginning of year capital) for some of the observations.
} 
with capital stock, while column (4) uses investment as an instrument for process innovation, but capital in the production function. Column (5) includes both investment and capital in both equations.

The results are somewhat encouraging: capital stock is clearly preferred in the production function. In fact, when it is included, investment enters only via its impact on process innovation. On the other hand, investment is a better predictor of process innovation, although capital still plays a role. However, recall that innovation is measured over the preceding three years, so that some of the investment associated with process innovation is likely to be already included in beginning of year capital. Our conclusion is that there is a strong association of process innovation with capital investment, and that such process innovation has a large impact on productivity.

\subsection{Comparison to Griffith et al. 2006}

The results shown in the previous section can help in shedding some light on the R\&Dinnovation-productivity relationship in Italian firms. Interesting insights can be gained from the differential impact of $\mathrm{R} \& \mathrm{D}$ on process and product innovation, as well as their different impact on productivity. Nevertheless, at this point, it is worth asking a further question: is the R\&D-innovation-productivity link different for Italian firms when they are compared to other European countries? In order to answer this question, we built building a slightly different sample of firms from our data that removed firms with fewer than 20 employees and included firms with more than 250 employees. ${ }^{13}$ Using this sample, we are able to compare our results to those for France, Germany, Spain and the UK (Griffith et al, 2006),. Table 6 shows results from Griffith et al. 2006 for the four countries and for a variation of our model applied to these data for Italy. ${ }^{14}$ The last column but one is for the year 2000 and the final column is for all three time periods $(1997,2000,2003)$.

\footnotetext{
${ }^{13}$ The overlap of this sample with the sample used in the main body of the paper is $75 \%$.

${ }^{14}$ For precise comparability with the earlier paper, in this table we estimated the process and product innovation equations using single probits rather than a bivariate probit. This is consistent, but not efficient, given the correlation between the two equations.
} 
The table shows that the results for Italy are roughly comparable with those for the other countries, but that the year 2000 seems to be a bit of an outlier. We do not have an explanation for this fact other than to point out that this period (1998-2000) corresponds to the introduction of the euro. We therefore focus on the results for the three periods 1995-1997, 1998-2000, 2001-2003 pooled together. R\&D intensity is somewhat more strongly associated with process innovation than in the UK, and much less strongly than in the other countries. Investment intensity is somewhat more strongly related to process innovation than in the other countries. Also noteworthy is that for Italy, the explanatory power of the innovations equations is considerably lower. In the productivity equation, only investment intensity enters, although product innovation has a large but insignificant impact, larger than that for any of the other countries. Together with the results for the innovation equations, this suggests that the variability in the $R \& D$-innovation-productivity relationship is much greater for Italy than for the other countries. However, there is nothing obviously different about the relationship itself when compared to its peers in Europe, apart from the fact that $R \& D$ is less closely linked to process innovation in Italian firms.

\section{Conclusions and policy discussion}

In this paper we have proposed and estimated a structural model that links R\&D decisions, innovation outcomes and productivity at the firm level. Based upon a modified version of the model earlier developed by Crépon, Duguet and Mairesse (1998), we were able to take into account also those firms which do not do (or report) explicitly R\&D. Innovation activity, especially among small firms, can operate along several dimensions besides formal $R \& D$.

Although preliminary, our results indicate that firm size is negatively associated with the intensity of $R \& D$, but positively with the likelihood of having product or process innovation. We have argued that these two findings are not inconsistent, given the nature of the variables. Having received a subsidy boosts R\&D efforts - or just the likelihood of reporting, more in high tech industries, even if the share of targeted firms is roughly the same in high and low tech sectors (46 vs. $45 \%$ ). Given firms' unwillingness to reveal more details about the subsidies received, we can only speculate about the possibility that high tech firms are more likely to receive funding 
for innovation and $\mathrm{R} \& \mathrm{D}$ than low tech firms. International (including European) competition fosters R\&D intensity, especially in high-tech firms. Also, R\&D has a strong and sizeable impact on firm's ability to produce process innovation, and a somewhat higher impact on product innovation. Investment in new equipment and machinery matters more for process innovation than for product innovation.

While interpreting these results, one should keep in mind the dual nature of R\&D. In fact, Cohen and Levinthal (1989) show that R\&D investments develop the firm's ability to identify, assimilate, and exploit knowledge from the environment. In other words, a minimum level of $\mathrm{R} \& \mathrm{D}$ activity is a necessary condition to benefit from spillovers and to appropriate public knowledge. On the other hand, more recent studies have suggested the emergence of a different knowledge paradigm, i.e. the one of innovation without research, particularly well suited for SMEs (Cowan and van de Paal, 2000), based on "the recombination and re-use of known practices", as David and Foray point out (1995).

Concerning the impact of innovation outcomes, product innovation has a positive impact on firms' labor productivity, but process innovation exerts the largest effect, via the associated investment. Moreover, larger and older firms seem to be, to a certain extent, less productive, ceteris paribus.

With respect to the broader questions that motivated this investigation, we note that in most respects Italian firms resemble those in other large European countries, with the possible exception that they do somewhat less $R \& D$, and their $R \& D$ is less tightly linked to process innovation, although they are no less innovative, at least according to their own reports. Surprisingly, in this sample, they are more rather than less productive per employee than firms in other countries. Although the firms in our sample, like Italian industry as a whole, exhibit a negative labor productivity growth during the 2000-2003 period, it does not seem to be associated with less productive innovative activity. Thus it appears to be difficult to find strong evidence of innovation "underperformance" in these data, other than the observation that those firms which do $\mathrm{R} \& \mathrm{D}$ do somewhat less on average than firms in their peer countries.

In general, "underinvestment" relative to others may be due to demand factors (perceived market size, consumer tastes, etc.), supply factors (high costs of capital or other inputs, availability of inputs, and the regulatory environment). Stepping outside 
traditional economic analysis, factors such as having goals other than profit maximization, limited information about opportunities, or even social and cultural norms can also influence investment in innovation. Choosing among these alternatives definitively is beyond the scope of this paper, but we offer a few thoughts on the supply side here.

There is limited evidence that lower rates of $R \& D$ investment in larger Italian firms is due to the fact that they face a higher cost of capital than other firms in continental Europe. In a comparative analysis, Hall and Oriani (2006) find high marginal stock market values for Italian $R \& D$ investment in large firms that do not have a majority shareholder, which suggests a high required rate of return and therefore a high cost of capital. However for the other firms (closely held), R\&D is not valued at all, which carries the implication that investment in these firms may not be profit driven. These conclusions suggests that a "bank-centered" capital market system, such as the Italian one, with a shortage of specialized suppliers like venture capitalists (Rajan and Zingales, 2003), is less capable of valuing R\&D projects (Hall, 2002). Additionally, smaller firms and those family-controlled firms that have a pyramid structure, which are quite important in Italy, are likely to be affected by credit rationing problems and/or to have goals other than profit-maximization. But this is to some extent speculative, and we hope to explore the question further in the future using these data.

\section{Acknowledgements}

We would like to thank the Mediocredito-Capitalia (now Unicredit) research department for having kindly supplied firm level data for this project. We thank also Susanto Basu, Ernie Berndt, Piergiuseppe Morone, Stéphane Robin, Mike Scherer, Enrico Santarelli, Alessandro Sembenelli, Marco Vivarelli, and participants at the NBER Productivity Seminars and at the workshop "Drivers and Impacts of Corporate R\&D in SMEs" held in Seville at IPTS. The views expressed by the authors do not necessarily reflect those of the Bank of Italy. 


\section{References}

Acs, Z. J., and D. B. Audretsch (1988), "Innovation in Large and Small Firms: an Empirical Analysis", American Economic Review, Vol. 78(4), pp. 678-69.

Acs, Z. J., and D. B. Audretsch (1990), Innovation and Small Firms, MIT Press, Cambridge, MA.

Amemiya, T. (1984), “Tobit Models: a Survey”, Journal of Econometrics, Vol. 24(12), pp. 3-61.

Baldwin, J. R., D. Beckstead, and R. Caves (2002), "Changes in the Diversification of Canadian Manufacturing Firms (1973-1997): a Move to Specialization. Research Paper Series 11F0019MIE2002179, Statistics Canada.

Baldwin, J. R. and W. Gu (2003), "Participation in Export Markets and Productivity Performance in Canadian Manufacturing", Canadian Journal of Economics, Vol. 36(3), pp. 634-657.

Benavente, J. M. (2006), "The Role of Research and Innovation in Promoting Productivity in Chile", Economics of Innovation and New Technology. Vol. 15(4/5), pp. 301-315.

Blundell, R., R. Griffith, and J. Van Reenen, (1993), “Knowledge Stocks, Persistent Innovation and Market Dominance: Evidence from a Panel of British Manufacturing Firms", Institute for Fiscal Studies, working paper N. W93/19.

Bönte, W (2003), "R\&D and Productivity: Internal vs. External R\&D - Evidence from West German Manufacturing Industries", Economics of Innovation and New Technology, Vol. 12, pp. 343-360.

Brandolini, A., P. Casadio, P. Cipollone, M. Magnani, A. Rosolia, and R. Torrini (2007), "Employment Growth in Italy in the 1990s: Institutional Arrangements and Market Forces", in Social Pacts, Employment and Growth, N. Acocella and R. Leoni Editors, Physica-Verlag HD.

Cohen, W. M., and S. Klepper (1996), “A Reprise of Size and R\&D”, The Economic Journal, Vol. 106(437), pp. 925-951.

Cohen W. M., and D. A. Levinthal (1989), "Innovation and Learning: The Two Faces of R\&D”, The Economic Journal, Vol. 99(397), pp. 569-596.

Cowan, R. and G. van de Paal (2000), "Innovation Policy in the Knowledge-Based Economy”, European Commission DG-Enterprise, Brussels.

Crépon, B., E. Duguet, and J. Mairesse (1998), "Research, Innovation and Productivity: an Econometric Analysis at the Firm Level", Economics of Innovation and New Technology, Vol. 7(2), pp. 115-158.

Das, M., W. K. Newey, and F. Vella (2003), "Nonparametric Estimation of Sample Selection Models", Review of Economic Studies, Vol. 70(1), pp. 33-58.

Daveri, F., and C. Jona-Lasinio (2005), "Italy's Decline: Getting the Facts Right", Giornale degli Economisti, Vol. 64(4), pp. 365-410.

David, P., and D. Foray (1995), "Accessing and Expanding the Science and Technology Knowledge Base", STI Review, n. 16, pp. 16-38. 
European Commission (2006), European Trend Chart on Innovation. Country Report, Italy. Enterprise Directorate-General.

Griffith, R., E. Huergo, J. Mairesse, and B. Peters (2006), "Innovation and Productivity across Four European Countries", Oxford Review of Economic Policy, Vol. 22(4), pp. 483-498.

Griliches, Z. (1995), "R\&D and Productivity: Econometric Results and Measurement Issues", in: Stoneman, P. (ed.), Handbook of the Economics of Innovation and Technological Change, Oxford, 52-89.

Griliches, Z. (1998), $R \& D$ and Productivity: The Econometric Evidence, Chicago University Press.

Hall, B. H., and J. Mairesse (2006), "Empirical Studies of Innovation in The Knowledge-Driven Economy”, Economics of Innovation and New Technology. Vol. 15(4/5), pp. 289-299.

Hall, B. H., and J., Mairesse (1995), "Exploring the relationship between R\&D and productivity in French manufacturing firms", Journal of Econometrics, Vol. 65(1), pp. 263-293.

Hall, B. H., F. Lotti, and J. Mairesse (2008), "Employment, Innovation and Productivity: Evidence from Italian Microdata", Industrial and Corporate Change, Vol. 17, pp. 813-839.

Hall, B. H., and R. Oriani (2006), "Does the Market Value R\&D Investment by European Firms? Evidence from a Panel of Manufacturing Firms in France, Germany, and Italy", International Journal of Industrial Organization, Vol. 24(5), pp. 971-993.

Harhoff, D., (1998), "R\&D and Productivity in German Manufacturing Firms",. Economics of Innovation and New Technology, Vol. 6(1), pp. 29-49.

Heckman, J. (1979), "Sample Selection Bias as a Specification Error", Econometrica, Vol. 47(1), pp. 153-161.

Heshmati, A., and H. Lööf (2006), "On the Relation between Innovation and Performance: a Sensitivity Analysis", Economics of Innovation and New Technology. Vol. 15(4/5), pp. 317-344.

Hoffman, K., M. Parejo, J. Bessant, and L. Perren (1998), "Small Firms, R\&D, Technology and Innovation in the UK: a Literature Review", Technovation, Vol. 18(1), pp. 39-55.

Janz, N., H. Lööf, and A. Peters (2004), "Firm Level Innovation and Productivity - Is there a Common Story across Countries?", Problems and Perspectives in Management, Vol. 2, pp. 1-22.

Jefferson, G. H., B. Huamao, G. Xiaojing, and Y. Xiaoyun (2006), "R\&D Performance in Chinese Industry", Economics of Innovation and New Technology. Vol. 15(4/5), pp. 345-366.

Kleinknecht, A. (1987), "Measuring R\&D in Small Firms: How Much are we Missing?", The Journal of Industrial Economics, Vol. 36(2), pp. 253-256.

Klette, T. J., and S. Kortum (2004), "Innovating Firms and Aggregate Innovation", Journal of Political Economy, Vol. 112(5), pp. 986-1018. 
Klette, T. J., and F. Johansen (1996), "Accumulation of R\&D Capital and Dynamic Firm Performance: A Not-so-fixed Effect Model”, Discussion Papers 184, Research Department of Statistics Norway.

Klomp, L., and G. Van Leeuwen (2001), "Linking Innovation and Firm Performance: A New Approach", International Journal of the Economics of Business, Vol. 8(3), pp. 343-364.

Lichtenberg, F. R., and D. Siegel (1991), "The Impact of R\&D Investment on Productivity: New Evidence using Linked R\&D-LRD Data", Economic Inquiry, Vol. 29(2), pp. 203-228.

Lotti, F., and E. Santarelli (2001), "Linking Knowledge to Productivity: a GermanyItaly Comparison Using the CIS Database", Empirica, Vol. 28, pp. 293-317.

Lööf, H., and A. Heshmati (2002), "Knowledge Capital and Performance Heterogeneity: a Firm Level Innovation Study", International Journal of Production Economics Vol. 76(1), pp. 61-85.

Mairesse, J., and M. Sassenou (1991), "R\&D Productivity: A Survey of Econometric Studies at the Firm Level", NBER Working Paper n. 3666.

Mairesse, J., and P. Mohnen (2005), "The Importance of R\&D for Innovation: A Reassessment Using French Survey Data", The Journal of Technology Transfer, special issue in memory of Edwin Mansfield, Vol. 30(1-2), pp. 183-197.

Mohnen, P., J. Mairesse, and M. Dagenais (2006), "Innovativity: a Comparison across Seven European Countries", Economics of Innovation and New Technology. Vol. 15(4/5), pp. 391-413.

Pakes, A., and Z. Griliches (1984), "Patents and R\&D at the Firm Level: A First Look", in: Griliches, Z. (ed.), R\&D, Patents, and Productivity, Chicago, pp. 55-71.

Parisi, M. L., F. Schiantarelli, and A. Sembenelli (2006), "Productivity, Innovation and R\&D: Micro Evidence for Italy", European Economic Review, Vol. 50, pp. 2037-2061.

Pianta, M, and A. Vaona (2007), "Innovation and Productivity in European Industries", Economics of Innovation and New Technology, Vol. 16(7), pp. 485-499.

Potters, L., R. Ortega-Argilés, and M. Vivarelli (2008), "R\&D and Productivity: Testing Sectoral Peculiarities using Micro Data", IZA Discussion Paper N. 3338.

Rajan, R. G., and L. Zingales (2003), "Banks and Markets: The Changing Character of European Finance", NBER Working Paper n. 9595.

Van Leeuwen, G. (2002), "Linking Innovation to Productivity Growth Using Two Waves of CIS”, STI working paper 2002/8, OECD.

Van Leeuwen, G. and L. Klomp (2006), "On the Contribution of Innovation to MultiFactor Productivity Growth", Economics of Innovation and New Technology. Vol. 15(4/5), pp. 367-390.

Vella, F. (1998), "Estimating Models with Sample Selection Bias: A Survey", The Journal of Human Resources, Vol. 33(1), pp. 127-169.

Verspagen, B. (1995), "R\&D and Productivity: a Broad Cross-Section Cross-Country Look", Journal of Productivity Analysis, Vol. 6, pp. 117-135 
Table 1 - Descriptive statistics, unbalanced and balanced sample

\begin{tabular}{|c|c|c|}
\hline Period: 1995-2003 & Unbalanced sample & Balanced sample \\
\hline Number of observations (firms) & $9,674(7,375)$ & $1,083(361)$ \\
\hline Continuous R\&D engagement (in \%) & 41.49 & 26.04 \\
\hline$R \& D$ intensity (for $R \& D$ doing firms, in logs)* & 1.08 & 1.02 \\
\hline Innovator (process and/or product, in \%) & 62.05 & 66.39 \\
\hline Process innovation (in \%) & 50.75 & 53.65 \\
\hline Product innovation (in \%) & 34.85 & 40.63 \\
\hline Process \& product innovation (in \%) & 20.94 & 25.39 \\
\hline Process innovation only (in \%) & 27.21 & 25.76 \\
\hline Share of sales with new products (in \%) & 22.16 & 22.98 \\
\hline Labor productivity: mean/median* & $4.99 / 4.94$ & $4.94 / 4.85$ \\
\hline Investment intensity: mean/median* & $7.90 / 4.05$ & $6.92 / 4.01$ \\
\hline Public support (in \%) & 45.49 & 50.51 \\
\hline Regional competitors (in \%) & 16.84 & 14.87 \\
\hline National competitors (in \%) & 42.24 & 41.37 \\
\hline European competitors (in \%) & 17.53 & 18.10 \\
\hline International (non EU) competitors (in \%) & 13.56 & 17.17 \\
\hline Large competitors (in \%) & 36.18 & 34.16 \\
\hline$\%$ of firm in size class $(11-20)$ & 30.04 & 19.67 \\
\hline$\%$ of firm in size class $(21-50)$ & 38.85 & 44.04 \\
\hline$\%$ of firm in size class $(51-250)$ & 31.11 & 36.29 \\
\hline$\%$ of firm in age class $(<15 \mathrm{yrs})$ & 32.45 & 24.10 \\
\hline$\%$ of firm in age class $(15-25 \mathrm{yrs})$ & 30.48 & 31.12 \\
\hline$\%$ of firm in age class $(>25)$ & 37.07 & 44.78 \\
\hline Number of employees: mean/median & $49.45 / 32$ & $53.48 / 36$ \\
\hline Group (in \%) & 20.07 & 16.25 \\
\hline
\end{tabular}

*Units are logs of euros (2000) per employee. 
Table 2 - Descriptive statistics, high tech and low tech industries.

\begin{tabular}{|c|c|c|}
\hline Period: 1995-2003 & High tech firms & Low tech firms \\
\hline Number of observations (firms) & $2,870(2,165)$ & $6,804(5,210)$ \\
\hline Continuous R\&D engagement (in \%) & 58.75 & 34.22 \\
\hline$R \& D$ intensity (for $R \& D$ doing firms, in logs)* & 1.20 & 0.98 \\
\hline Innovator (process and/or product, in \%) & 69.41 & 58.95 \\
\hline Process innovation (in \%) & 54.25 & 49.28 \\
\hline Product innovation (in \%) & 43.80 & 31.06 \\
\hline Process \& product innovation (in \%) & 25.57 & 18.72 \\
\hline Process innovation only (in \%) & 26.20 & 27.90 \\
\hline Share of sales with new products (in \%) & 22.63 & 21.88 \\
\hline Labor productivity: mean/median* & $4.93 / 4.89$ & $5.02 / 4.96$ \\
\hline Investment intensity: mean/median* & $6.22 / 3.36$ & $8.62 / 4.38$ \\
\hline Public support (in \%) & 46.27 & 45.16 \\
\hline Regional competitors (in \%) & 12.30 & 18.75 \\
\hline National competitors (in \%) & 36.45 & 44.68 \\
\hline European competitors (in \%) & 25.40 & 14.21 \\
\hline International (non EU) competitors (in \%) & 19.86 & 10.91 \\
\hline Large competitors (in \%) & 42.54 & 33.50 \\
\hline$\%$ of firm in size class $(11-20)$ & 27.25 & 31.22 \\
\hline$\%$ of firm in size class $(21-50)$ & 36.86 & 39.68 \\
\hline$\%$ of firm in size class $(51-250)$ & 35.89 & 29.10 \\
\hline$\%$ of firm in age class $(<15 \mathrm{yrs})$ & 32.79 & 32.30 \\
\hline$\%$ of firm in age class $(15-25 \mathrm{yrs})$ & 31.67 & 29.98 \\
\hline$\%$ of firm in age class $(>25)$ & 35.54 & 37.71 \\
\hline Number of employees: mean/median & $54.17 / 35$ & $47.46 / 30$ \\
\hline Group (in \%) & 25.26 & 17.89 \\
\hline
\end{tabular}

*Units are logs of euros (2000) per employee. 
Table 3 - R\&D intensity (STEP 1): OLS model. Dependent variable, R\&D intensity

\begin{tabular}{|c|c|c|c|}
\hline $\begin{array}{l}\text { R\&D Expenditure per employee } \\
\text { (in logarithms) }\end{array}$ & All firms & High Tech & Low Tech \\
\hline \multirow[t]{2}{*}{ D(Large firm competitors) } & 0.062 & 0.197 & -0.028 \\
\hline & $(0.073)$ & $(0.109)$ & $(0.098)$ \\
\hline \multirow[t]{2}{*}{$\mathrm{D}$ (Regional competitors) } & 0.094 & 0.548 & -0.049 \\
\hline & $(0.167)$ & $(0.320)$ & $(0.197)$ \\
\hline \multirow[t]{2}{*}{ D(National competitors) } & 0.138 & $0.638 *$ & -0.037 \\
\hline & $(0.147)$ & $(0.290)$ & $(0.172)$ \\
\hline \multirow[t]{2}{*}{$\mathrm{D}$ (European competitors) } & $0.511 * * *$ & $0.834 * *$ & $0.448^{*}$ \\
\hline & $(0.154)$ & $(0.287)$ & $(0.187)$ \\
\hline \multirow[t]{2}{*}{$\mathrm{D}$ (International competitors) } & $0.570 * * *$ & $1.034 * * *$ & 0.357 \\
\hline & $(0.159)$ & $(0.296)$ & $(0.195)$ \\
\hline \multirow[t]{2}{*}{$\mathrm{D}$ (Received subsidies) } & $0.389 * * *$ & $0.619 * * *$ & $0.213^{*}$ \\
\hline & $(0.072)$ & $(0.111)$ & $(0.095)$ \\
\hline \multirow[t]{2}{*}{$\mathrm{D}$ (Member of a group) } & $0.198^{*}$ & 0.247 & 0.165 \\
\hline & $(0.084)$ & $(0.128)$ & $(0.114)$ \\
\hline \multirow[t]{2}{*}{ Size class (21-50 empl.) } & $-0.271 * *$ & -0.141 & $-0.349 * *$ \\
\hline & $(0.104)$ & $(0.164)$ & $(0.134)$ \\
\hline \multirow[t]{2}{*}{ Size class (51-250 empl.) } & $-0.271^{*}$ & -0.123 & $-0.379 * *$ \\
\hline & $(0.109)$ & $(0.167)$ & $(0.145)$ \\
\hline \multirow[t]{2}{*}{ Age class (15-25 yrs) } & -0.009 & 0.032 & -0.032 \\
\hline & $(0.094)$ & $(0.141)$ & $(0.127)$ \\
\hline \multirow[t]{2}{*}{ Age class ( $>25 \mathrm{yrs})$} & -0.061 & -0.147 & -0.003 \\
\hline & $(0.090)$ & $(0.135)$ & $(0.120)$ \\
\hline R-squared & 0.061 & 0.065 & 0.038 \\
\hline Number of observations & 4,015 & 1,687 & 2,328 \\
\hline
\end{tabular}


Table 4 - A bivariate probit for process and product innovation dummies (STEP 2): all firms, high- and low- tech firms

\begin{tabular}{|c|c|c|c|c|c|c|}
\hline & \multicolumn{2}{|c|}{ All firms } & \multicolumn{2}{|c|}{ High-tech firms } & \multicolumn{2}{|c|}{ Low-tech firms } \\
\hline & (1) & (1a) & $(2)$ & (2a) & (3) & (3a) \\
\hline & Process Inno. & Product Inno. & Process Inno. & Product Inno. & Process Inno. & Product Inno. \\
\hline $\begin{array}{l}\text { Predicted R\&D intensity } \\
\text { (in logs) }\end{array}$ & $\begin{array}{c}0.483 * * *[0.193] \\
(0.045)\end{array}$ & $\begin{array}{c}0.686 * * *[0.250] \\
(0.045)\end{array}$ & $\begin{array}{c}0.256 * * *[0.102] \\
(0.056)\end{array}$ & $\begin{array}{c}0.499 * * *[0.196] \\
(0.056)\end{array}$ & $\begin{array}{c}0.602 * * *[0.240] \\
(0.069)\end{array}$ & $\begin{array}{c}0.749 * * *[0.261] \\
(0.069)\end{array}$ \\
\hline $\begin{array}{l}\text { Investment per employee } \\
\text { (in logs) }\end{array}$ & $\begin{array}{c}0.125 * * *[0.050] \\
(0.011)\end{array}$ & & $\begin{array}{c}0.120 * * *[0.047] \\
(0.021)\end{array}$ & & $\begin{array}{c}0.129 * * *[0.051] \\
(0.013)\end{array}$ & \\
\hline Size class (21-50 empl.) & $\begin{array}{c}0.255^{* * *}[0.101] \\
(0.033)\end{array}$ & $\begin{array}{c}0.310 * * *[0.115] \\
(0.035)\end{array}$ & $\begin{array}{c}0.159 *[0.063] \\
(0.062)\end{array}$ & $\begin{array}{c}0.126 *[0.050] \\
(0.063)\end{array}$ & $\begin{array}{c}0.350 * * *[0.139] \\
(0.043)\end{array}$ & $\begin{array}{c}0.431 * * *[0.153] \\
(0.046)\end{array}$ \\
\hline Size class (51-250 empl.) & $\begin{array}{c}0.446 * * *[0.175] \\
(0.037)\end{array}$ & $\begin{array}{c}0.504 * * *[0.189] \\
(0.038)\end{array}$ & $\begin{array}{c}0.276 * * *[0.108] \\
(0.068)\end{array}$ & $\begin{array}{c}0.299 * * *[0.118] \\
(0.067)\end{array}$ & $\begin{array}{c}0.606 * * *[0.237] \\
(0.048)\end{array}$ & $\begin{array}{c}0.679 * * *[0.248] \\
(0.049)\end{array}$ \\
\hline Age class (15-25 yrs) & $\begin{array}{c}0.009[0.004] \\
(0.034)\end{array}$ & $\begin{array}{c}0.050[0.018] \\
(0.034)\end{array}$ & $\begin{array}{c}0.004[0.001] \\
(0.061)\end{array}$ & $\begin{array}{c}0.036[0.014] \\
(0.061)\end{array}$ & $\begin{array}{c}0.020[0.008] \\
(0.040)\end{array}$ & $\begin{array}{c}0.058[0.020] \\
(0.042)\end{array}$ \\
\hline Age class (>25 yrs) & $\begin{array}{c}-0.003[-0.001] \\
(0.033)\end{array}$ & $\begin{array}{c}0.129 * * *[0.047] \\
(0.034)\end{array}$ & $\begin{array}{c}0.094[0.037] \\
(0.062)\end{array}$ & $\begin{array}{c}0.157 *[0.062] \\
(0.062)\end{array}$ & $\begin{array}{c}-0.067[-0.026] \\
(0.039)\end{array}$ & $\begin{array}{c}0.094 *[0.033] \\
(0.041)\end{array}$ \\
\hline $\begin{array}{l}\text { Rho } \\
\text { Pseudo R-squared }\end{array}$ & 0.10 & 0.08 & \multicolumn{2}{|c|}{$0.345^{* * * *}$} & \multicolumn{2}{|c|}{$0.430 * * *$} \\
\hline Number of obs. (firms) & \multicolumn{2}{|c|}{$9,674(7,375)$} & \multicolumn{2}{|c|}{$2,870(2,165)$} & \multicolumn{2}{|c|}{$6,804(5,210)$} \\
\hline
\end{tabular}


Table 5 - Production function (STEP 3): all firms, high- and low-tech firms

\begin{tabular}{|c|c|c|c|c|c|c|}
\hline \multirow{2}{*}{$\begin{array}{l}\text { Dep. variable: labor productivity } \\
\text { (sales per employee in logs) }\end{array}$} & \multicolumn{2}{|c|}{ All firms } & \multicolumn{2}{|c|}{ High-tech firms } & \multicolumn{2}{|c|}{ Low-tech firms } \\
\hline & (1) & (1a) & (2) & (2a) & (3) & (3a) \\
\hline Predicted probability of & $2.624 * * *$ & 0.193 & $2.742 * * *$ & 0.664 & $2.797 * * *$ & 0.063 \\
\hline process innovation only & $(0.146)$ & $(0.267)$ & $(0.304)$ & $(0.512)$ & $(0.171)$ & $(0.391)$ \\
\hline Predicted probability of & $0.961 * * *$ & $0.597 * * *$ & $1.314 * * *$ & $0.700 * * *$ & $0.900 * * *$ & $0.708 * * *$ \\
\hline product innovation & $(0.083)$ & $(0.093)$ & $(0.149)$ & $(0.200)$ & $(0.118)$ & $(0.122)$ \\
\hline Investment per employee & & $0.099 * * *$ & & $0.073 * * *$ & & $0.109 * * *$ \\
\hline (in logs) & & $(0.010)$ & & $(0.015)$ & & $(0.015)$ \\
\hline \multirow[t]{2}{*}{ Size class (21-50 empl.) } & $-0.184 * * *$ & $-0.136 * * *$ & $-0.140 * * *$ & $-0.085 * *$ & $-0.204 * * *$ & $-0.163 * * *$ \\
\hline & $(0.016)$ & $(0.017)$ & $(0.029)$ & $(0.031)$ & $(0.020)$ & $(0.021)$ \\
\hline \multirow[t]{2}{*}{ Size class (51-250 empl.) } & $-0.313 * * *$ & $-0.243 * * *$ & $-0.177 * * *$ & $-0.116^{* *}$ & $-0.391 * * *$ & $-0.321 * * *$ \\
\hline & $(0.023)$ & $(0.024)$ & $(0.037)$ & $(0.038)$ & $(0.031)$ & $(0.032)$ \\
\hline \multirow[t]{2}{*}{ Age class (15-25 yrs) } & -0.006 & -0.017 & $-0.0579 *$ & $-0.064 *$ & 0.0174 & 0.005 \\
\hline & $(0.016)$ & $(0.016)$ & $(0.026)$ & $(0.026)$ & $(0.020)$ & $(0.020)$ \\
\hline \multirow[t]{2}{*}{ Age class (>25 yrs) } & 0.008 & $-0.038 *$ & $-0.0764 * *$ & $-0.069 * *$ & $0.0469 *$ & -0.036 \\
\hline & $(0.016)$ & $(0.016)$ & $(0.027)$ & $(0.027)$ & $(0.020)$ & $(0.022)$ \\
\hline R-squared & 0.209 & 0.219 & 0.194 & 0.201 & 0.227 & 0.226 \\
\hline Number of observations (firms) & \multicolumn{2}{|c|}{$9,674(7,375)$} & \multicolumn{2}{|c|}{$2,870(2,165)$} & \multicolumn{2}{|c|}{$6,804(5,210)$} \\
\hline
\end{tabular}


Table 6 - Comparison with Griffith et al. (2006)

\begin{tabular}{|c|c|c|c|c|c|c|c|c|c|c|c|c|}
\hline Period: 1998-2000 & \multicolumn{2}{|c|}{ France } & \multicolumn{2}{|c|}{ Germany } & \multicolumn{2}{|c|}{ Spain } & \multicolumn{2}{|c|}{$U K$} & \multicolumn{2}{|c|}{ Italy } & \multicolumn{2}{|c|}{ Italy (a) } \\
\hline Number of observations & \multicolumn{2}{|c|}{3,625} & \multicolumn{2}{|l|}{1,123} & \multicolumn{2}{|c|}{3,588} & \multicolumn{2}{|c|}{1,904} & \multicolumn{2}{|c|}{2,594} & \multicolumn{2}{|c|}{8,377} \\
\hline \multicolumn{13}{|c|}{ Process innovation equation } \\
\hline R\&D intensity $\dagger$ & 0.303 & $* * *$ & 0.260 & $* * *$ & 0.281 & $* * *$ & 0.161 & $* * *$ & 0.146 & $* * *$ & 0.192 & $* * *$ \\
\hline \multicolumn{13}{|c|}{ Product innovation equation } \\
\hline $\mathrm{R} \& \mathrm{D}$ intensity $\dagger$ & 0.440 & $* * *$ & 0.273 & $* * *$ & 0.296 & $* * *$ & 0.273 & $* * *$ & 0.192 & $* * *$ & 0.303 & $* * *$ \\
\hline Pseudo R-squared & 0.360 & & 0.313 & & 0.249 & & 0.258 & & 0.058 & & 0.081 & \\
\hline \multicolumn{13}{|c|}{ Labor Productivity equation } \\
\hline Product Innovation & 0.060 & $* * *$ & -0.053 & & 0.176 & $* * *$ & 0.055 & $* * *$ & 1.152 & & 0.384 & \\
\hline R-squared & 0.290 & & 0.280 & 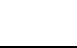 & 0.180 & & 0.190 & & 0.166 & & 0.227 & \\
\hline
\end{tabular}


Figure 1 - Value added per employee. Percentage change, annual rate (1995-2000 and 2000-2005). Total manufacturing.

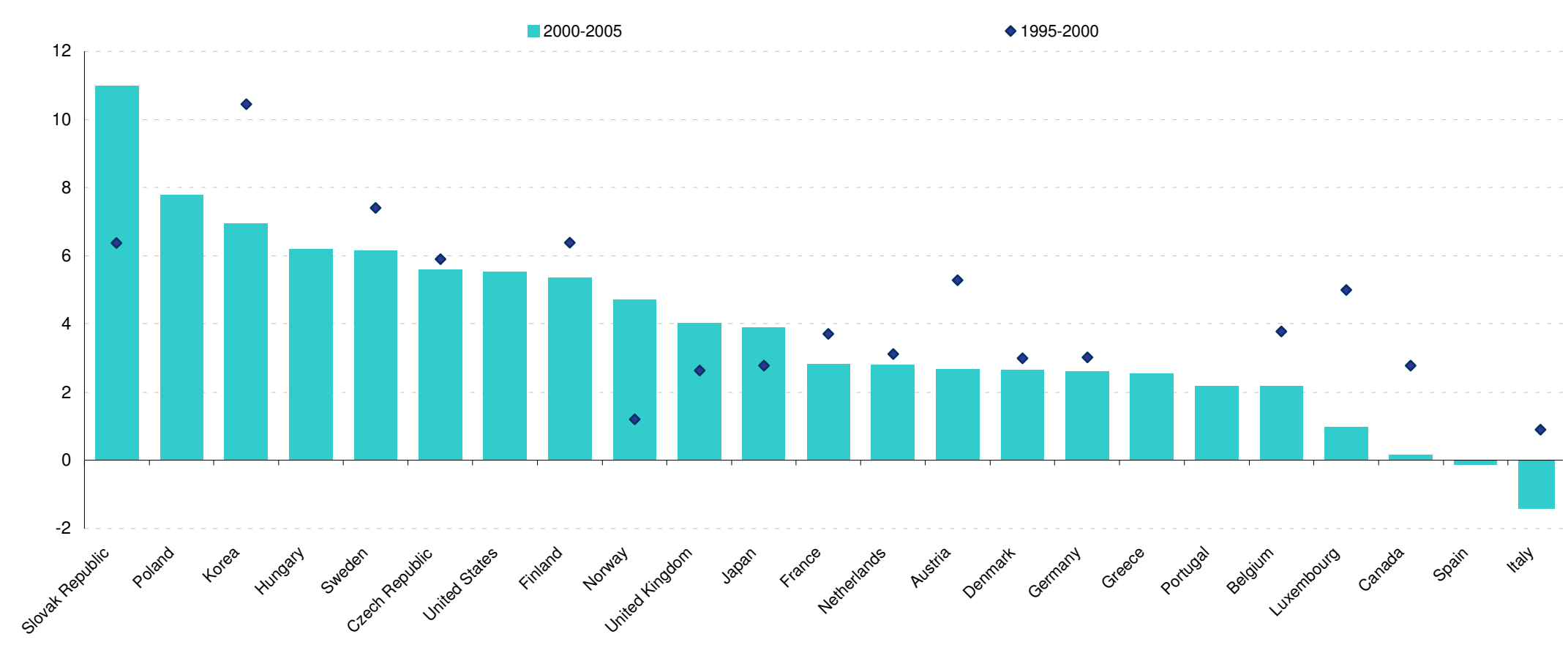

Source: OECD Factbook, April 2008. Permanent link http://dx.doi.org/10.1787/271772787380 
Figure 2 - Size distribution of Italian firms (2001) and share of firms with innovation by size class (2002-2004).

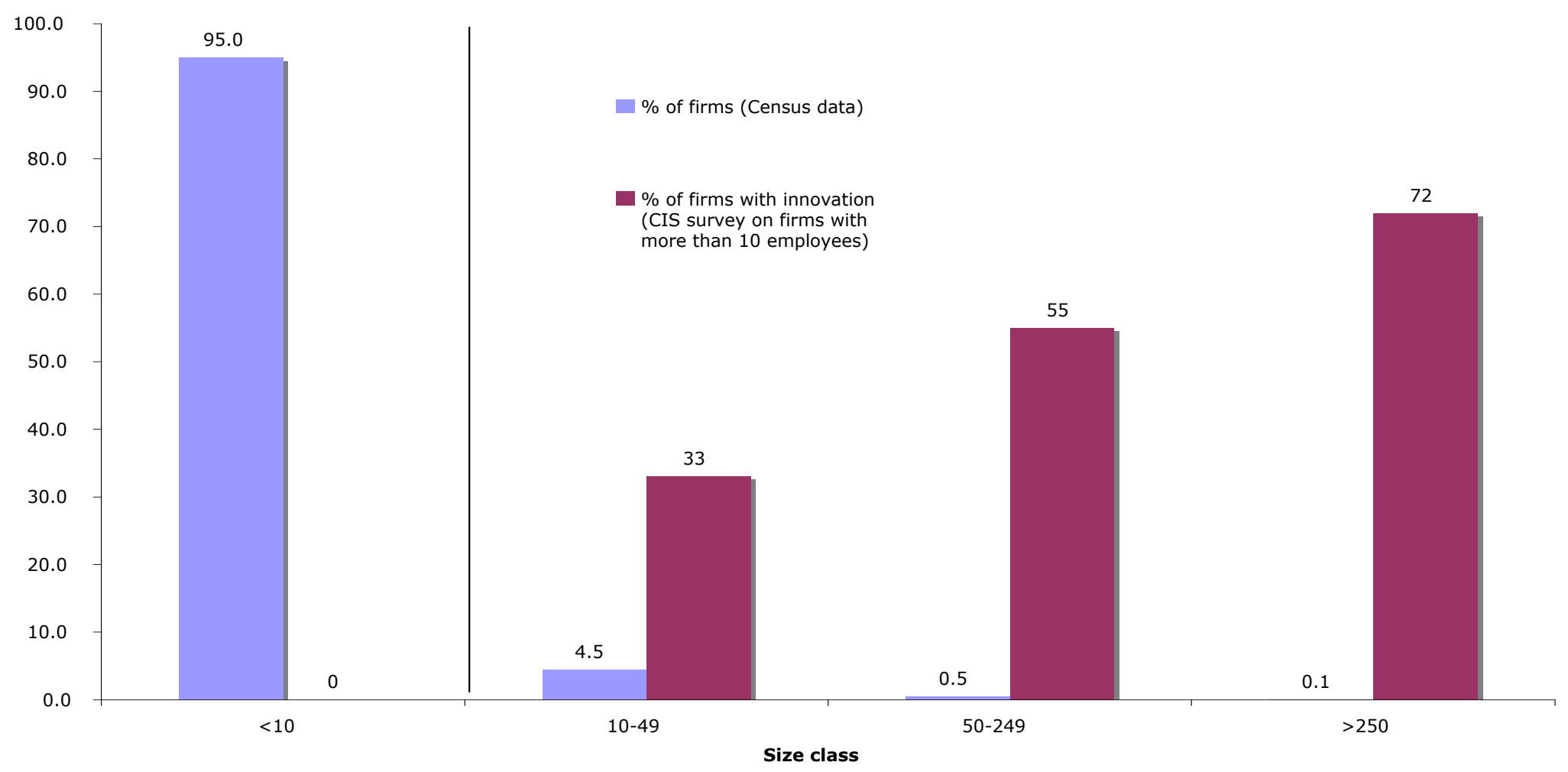

Source: National Institute of Statistcs (ISTAT). Census of Manufacturing and Services (2001) for the size distribution. Community innovation survey (CIS) for the presence of innovation activity (2002-2004). 


\section{Appendix}

\section{Variable Definitions}

$R \& D$ engagement: dummy variable that takes value 1 if the firm has positive $\mathrm{R} \& \mathrm{D}$ expenditures over the three year of each wave of the survey.

$R \& D$ intensity: $\mathrm{R} \& \mathrm{D}$ expenditures per employee, in real terms and in logs.

Process innovation: dummy variable that takes value 1 if the firm declares to have introduced a process innovation during the three years of the survey.

Product innovation: dummy variable that takes value 1 if the firm declares to have introduced a product innovation during the three years of the survey.

Innovator: dummy variable that takes value 1 if the firm has process or product innovation.

Share of sales with new products: percentage of the sales in the last year of the survey coming from new or significantly improved products (in percentage).

Labor productivity: real sales per employee, in logs.

Investment intensity: investment in machinery per employee, in logs.

Public support: dummy variable that takes value 1 if the firm has received a subsidy during the three years of the survey.

Regional - National - European -International (non EU) competitors: dummy variables to indicate the location of the firm's competitors.

Large competitors: dummy variable that takes value 1 if the firm declares to have large firms as competitors.

Employees: number of employees, headcount.

Age: firm's age (in years).

Size classes: [11-20], [21-50], [51-250] employees.

Age classes: $[<15],[15-25],[>25]$ years.

Industry dummies: a set of indicators for a 2-digits industry classification.

Time dummies: a set of indicators for the year of the survey. 
Wave dummies: a set of indicators for firm's presence or absence in the three waves of the survey

High-tech firms: encompasses high and medium-high technology industries (chemicals; office accounting \& computer machinery; radio, TV \& telecommunication instruments; medical, precision \& optical instruments; electrical machinery and apparatus, n.e.c.; machinery \& equipment; railroad \& transport equipment, n.e.c.).

Low-tech firms: encompasses low and medium-low technology industries (rubber \& plastic products; coke, refined petroleum products; other non-metallic mineral products; basic metals and fabricated metal products; manufacturing n.e.c.; wood, pulp \& paper; food, beverages \& tobacco products; textile, textile products, leather \& footwear).

Capital stock: fixed capital stock, in real terms, computed by a perpetual inventory method with constant depreciation rate $(\delta=0.05)$. The starting value is the accounting value as reported in firm's balance sheets. 
Table A1 - A comparison of selected variables for France, Germany, Spain, UK and Italy.

\begin{tabular}{|c|c|c|c|c|c|c|}
\hline Period: 1998-2000 & France & Germany & Spain & $U K$ & Italy & Italy (b) \\
\hline Number of observations (firms) & 3,625 & 1,123 & 3,588 & 1,904 & 2,594 & 8,377 \\
\hline Continuous R\&D engagement (in \%) & 35.0 & 39.5 & 20.9 & 26.7 & 49.8 & 48.9 \\
\hline R\&D per employee (for R\&D-doers, mean) $\dagger$ & 6.9 & 5.2 & 4.3 & 3.6 & 2.9 & 2.4 \\
\hline Innovator (process and/or product, in \%) & 52.9 & 65.8 & 51.2 & 41.5 & 54.7 & 66.9 \\
\hline Process innovation (in \%) & 32.3 & 42.3 & 34.7 & 27.1 & 44.7 & 55.4 \\
\hline Product innovation (in \%) & 44.6 & 54.7 & 33.6 & 28.6 & 33.3 & 39.9 \\
\hline $\begin{array}{l}\text { Share of sales with new products } \\
\text { for firms with product innovation (in \%) }\end{array}$ & 16.5 & 29.5 & 32.7 & 30.8 & 32.2 & 22.5 \\
\hline Labor productivity (mean) $\dagger$ & 165.3 & 145.6 & 137.7 & 143.4 & 173.8 & 187.1 \\
\hline Investment per employee (mean) $\dagger$ & 6.0 & 8.3 & 8.3 & 6.3 & 8.0 & 7.9 \\
\hline \multicolumn{7}{|l|}{ Public support for innovation (in \%) } \\
\hline Local & 5.5 & 15.8 & 14.0 & 4.5 & & \\
\hline National & 15.4 & 21.2 & 12.5 & 3.6 & 49.9 (a) & $50.6(a)$ \\
\hline $\mathrm{EU}$ & 5.1 & 8.1 & 3.3 & 1.7 & & \\
\hline$\%$ of firm in size class $(20-49)$ & 30.4 & 28.8 & 47.8 & 38.6 & 60.6 & 44.9 \\
\hline$\%$ of firm in size class $(50-250)$ & 39.6 & 42.8 & 37.5 & 39.3 & 27.8 & 36.7 \\
\hline$\%$ of firm in size class $(>250)$ & 30.0 & 28.5 & 14.7 & 22.1 & 11.1 & 18.4 \\
\hline
\end{tabular}

This table is a slightly modified version of Table 3 in Griffith et al. 2006. Data are from the third Community Innovation Survey (CIS 3) for France, Germany, Spain, and the UK. Data for Italy are from the Mediocredito Surveys. Among the several variables included in the original table, we selected only those comparable to our data. Data are not population-weighted. (a) This figure encompasses all the subsidies, regardless their source. (b) This column shows data for all 3 periods in Italy (1995-1997, 1998-2000, 2001-2003). †Units are logs of euros (2000) per employee. 


\section{Table A2 - A non-parametric selectivity test}

\begin{tabular}{|c|c|c|}
\hline Dependent variable & Prob(R\&D>0) & R\&D expend. per employee \\
\hline \multirow[t]{2}{*}{$\mathrm{D}$ (Large firms) } & $0.150 * * *$ & 0.305 \\
\hline & $(0.030)$ & $(0.436)$ \\
\hline \multirow[t]{2}{*}{ D(Regional) } & $-0.138 *$ & -0.230 \\
\hline & $(0.056)$ & $(0.408)$ \\
\hline \multirow[t]{2}{*}{ D(National) } & 0.012 & 0.0879 \\
\hline & $(0.051)$ & $(0.085)$ \\
\hline \multirow[t]{2}{*}{ D(European) } & $0.339 * * *$ & 0.826 \\
\hline & $(0.057)$ & $(0.988)$ \\
\hline \multirow[t]{2}{*}{ D(International) } & $0.391 * * *$ & 0.927 \\
\hline & $(0.060)$ & $(1.142)$ \\
\hline \multirow[t]{2}{*}{$\mathrm{D}$ (Public subsidies for innovation) $\dagger$} & $0.324 * * *$ & 0.761 \\
\hline & $(0.028)$ & $(0.943)$ \\
\hline \multirow[t]{2}{*}{ Group } & $0.145^{* * *}$ & 0.339 \\
\hline & $(0.037)$ & $(0.423)$ \\
\hline \multirow[t]{2}{*}{ Size class (21-50 empl.) } & $0.147 * * *$ & 0.200 \\
\hline & $(0.035)$ & $(0.431)$ \\
\hline \multirow[t]{2}{*}{ Size class (51-250 empl.) } & $0.482 * * *$ & 0.759 \\
\hline & $(0.040)$ & $(1.402)$ \\
\hline \multirow[t]{2}{*}{ Age class (15-25 yrs) } & 0.022 & 0.0258 \\
\hline & $(0.036)$ & $(0.089)$ \\
\hline \multirow{2}{*}{ Age class (>25 yrs) } & 0.064 & 0.0684 \\
\hline & $(0.036)$ & $(0.197)$ \\
\hline \multirow[t]{2}{*}{ Constant } & $-0.563 * * *$ & 499.4 \\
\hline & $(0.163)$ & $(424.583)$ \\
\hline \multirow[t]{2}{*}{ Predicted $\operatorname{Pr}(R \& D>0)$} & & 157.1 \\
\hline & & $(130.890)$ \\
\hline \multirow[t]{2}{*}{ Inverse Mill's ratio } & & 92.21 \\
\hline & & $(81.214)$ \\
\hline \multirow[t]{2}{*}{ Square Predicted $\operatorname{Pr}(\mathrm{R} \& D>0)$} & & -399.9 \\
\hline & & $(336.616)$ \\
\hline \multirow[t]{2}{*}{ Square Inverse Mill's ratio } & & 183.7 \\
\hline & & $(152.908)$ \\
\hline \multirow[t]{2}{*}{ Predicted $\operatorname{Pr}(R \& D>0) *$ Inverse Mill's ratio } & & 499.4 \\
\hline & & $(424.583)$ \\
\hline Industry, Time \& Wave dummies & Yes & Yes \\
\hline R-squared or pseudo R-squared & 0.114 & 0.143 \\
\hline Number of observations & 9,674 & 9,674 \\
\hline
\end{tabular}

Standard errors are robust and clustered at the firm level. $*=$ significant at $10 \%, * *=$ significant at $5 \%, * * *=$ significant at $1 \%$. From this probit model we computed, for each observation in the sample, the inverse Mills' ratio, the predicted probability of having positive $R \& D$ and their quadratic and interaction terms. $†$ This figure encompasses all the subsidies, regardless their source. 
Table A3 - Robustness check for step 2 and 3.

(1)

(2)

(3)

(4)

\section{Step 2 - Process Innovation}

Predicted R\&D intensity

$0.483 * * *[0.193]$

(0.045)

$0.544 * * *[0.217]$

$0.476 * * *[0.190]$

$(0.045)$

$0.547 * * *[0.218]$

(0.045)

$0.137 * * *[0.055]$

Investment intensity

$0.125 * * *[0.050]$

$(0.011)$

$(0.011)$

\section{Step 2 - Product Innovation}

Predicted R\&D intensity

$0.686 * * *[0.250]$

$0.677 * * *[0.247]$

$0.660 * * *[0.241]$

(0.046)

(0.045)

$(0.045)$

(0.046)

$0.055 * * *[0.020]$

Investment intensity

$0.021 *[0.008]$

$(0.011)$

$(0.011)$

\section{Step 3 - Productivity including investment in the equation}

Predicted process inno

0.193

$-0.395$

0.010

$-0.432$

(0.267)

(0.275)

(0.255)

(0.277)

Predicted product inno

$0.597 * * *$

$0.554 * * *$

$0.599 * * *$

$0.538 * * *$

(0.093)

(0.087)

(0.095)

(0.086)

Investment intensity

$0.099 * * *$

$0.099 * * *$

$0.093 * * *$

$0.105 * * *$

(0.010)

(0.006)

(0.009)

(0.006)

\section{Step 3 - Productivity without investment in the equation}

Predicted process inno

Predicted product inno

$$
2.624 * * *
$$

$0.961 * * *$

(0.083)
$-1.318^{* * *}$

(0.279)

$0.895 * * *$

(0.087)
$2.286 * * *$

(0.168)

$1.133 * * *$

(0.079)
$-0.171$

(0.280)

$0.773 * * *$

(0.087)

$\overline{\text { Coefficients, marginal effects for step } 2 \text { in square brackets, and standard errors are shown. The standard errors are robust to heteroskedasticity and clustered at the }}$ firm level. $*=$ significant at $10 \%, * *=$ significant at $5 \%, * * *=$ significant at $1 \%$. Industry, wave, and time dummies are included in all equations. Reference groups: $\mathrm{D}$ (provincial competitors), Size class $(11-50 \mathrm{empl})$, Age class $(<15 \mathrm{yrs})$. Specifications (1)-(4) encompass alternative assumptions for investment, whether it is devoted to process or product innovation, neither, or both. 
Table A4 - Robustness check using lagged capital and ML estimation (9014 observations)

(1)

(2)

(3)

(4)

(5)

investment in process, capital

with investment with investment with capital in productivity

with both

Method of estimation:

Sequential

pooled $M L$

pooled $M L$

pooled $M L$

pooled $M L$

\section{Step 2 - Process Innovation}

Predicted R\&D intensity

$0.440 * * *$

$0.400 * * *$

$0.416 * * *$

$0.399 * * *$

$0.389 * * *$

$(0.048)$

(0.074)

$(0.078)$

(0.073)

(0.075)

Log investment

$0.131 * * *$

$0.142 * * *$

$0.145 * * *$

$0.120 * * *$

per employee

$(0.011)$

(0.013)

(0.011)

(0.013)

Log capital stock $\dagger$

$0.098^{* * *}$

$0.041 * * *$

per employee

(0.013)

(0.014)

\section{Step 2 - Product Innovation}

Predicted R\&D intensity

$0.652 * * *$

$0.656 * * *$

$0.655^{* * *}$

$0.658 * * *$

$0.661 * * *$

$(0.047)$

(0.094)

$(0.094)$

$(0.093)$

(0.095)

\section{Step 3 - Productivity equation}

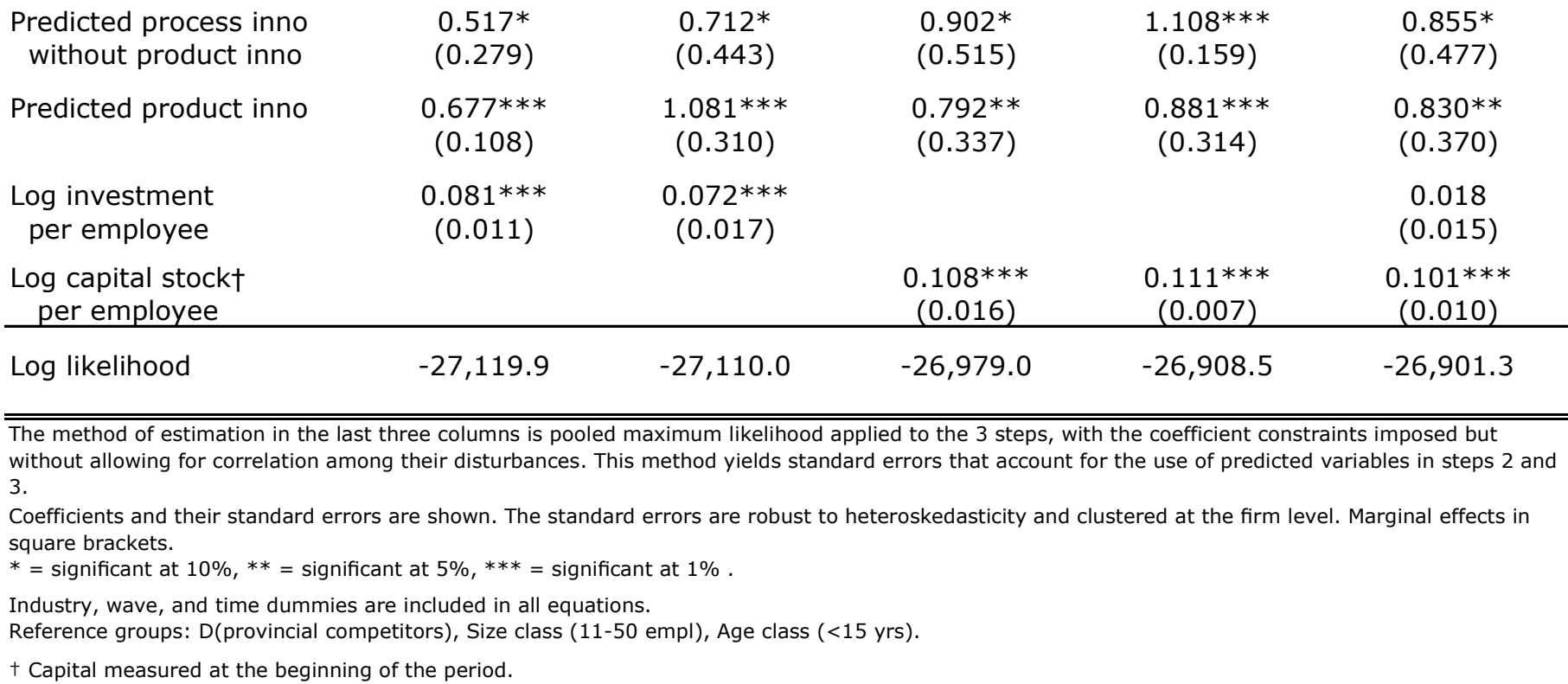

